\title{
O eixo conurbado entre Maringá e Sarandi (PR): um estudo geoeconômico
}

\section{Resumo}

O Contorno Norte de Maringá (PR) é uma obra de intervenção urbana, realizada com recursos do Programa de Aceleração do Crescimento, PAC. Devido à localização da obra ser na divisa entre as cidades de Maringá e Sarandi, buscamos, neste estudo, compreender quais foram as influências dessa configuração na dinâmica dos espaços ocupados no eixo conurbado dos municípios. A análise dos dados obtidos permitiu avaliar que o Contorno Norte facilitou o movimento dos negócios, a viabilização da entrada e saída de caminhões, bem como a agilidade nas entregas. Ambos os municípios se beneficiaram da obra, em relação ao favorecimento de novos empreendimentos, embora haja relatos de trânsito intenso na divisa entre Maringá e Sarandi. O fluxo de veículos na Avenida Colombo apresentou melhora após a finalização do Contorno, apesar de terem sido constatadas reclamações quanto à localização da obra, posicionada na entrada/saída de duas cidades e em grande parte do entroncamento do Contorno Sul, o que torna confuso o acesso às empresas localizadas na Avenida Colombo e favorece a ocorrência de acidentes de trânsito. Concluiu-se que a obra não fomenta impactos negativos para os empreendimentos e permitiu maior integração, não somente entre as cidades em questão, mas à região.

Palavras-chave: Conurbação. Planejamento urbano. Economia. Paraná Região Norte.

\section{Jaqueline Longen Rossatto}

Especialista em Ensino e Pesquisa na Ciência Geográfica pela

Universidade Estadual do Centro-

Oeste - UNICENTRO-PR.

Brasil

jaque.Ir@hotmail.com

\section{Lisandro Pezzi Schmidt}

Doutor em Geografia pela Univ. Federal de Santa Catarina - UFSC.

Docente da Univ. Estadual do

Centro-Oeste-UNICENTRO-PR. Brasil

Ipezzi@unicentro.br

\section{Pierre Alves Costa}

Doutor em História pela Univ.

Federal Fluminense -UFF. Docente da

Universidade Estadual do Centro-

Oeste - UNICENTRO-PR

Brasil

alvespierre75@hotmail.com

\section{Para citar este artigo:}

ROSSATTO, Jaqueline Longen; SCHMIDT, Lisandro Pezzi; COSTA, Pierre Alves. O eixo conurbado entre Maringá e Sarandi (PR): um estudo geoeconômico. Revista PerCursos, Florianópolis, v. 21, n.45, p. 202 231, jan./abr. 2020.

\section{DOI: $10.5965 / 1984724621452020202$}

http://dx.doi.org/10.5965/1984724621452020202 


\section{The conurbated axis between Maringá and Sarandi (PR): a geoeconomic study}

The public work betwen in the cities of the de Maringá and Sarandi, in the state of Paraná, Brazil, is an urban intervention project, carried out with resources from the Growth Acceleration Program, PAC, Brazil. Due to the location being on the between the cities of Maringá and Sarandi, we sought, in this study, to understand what were the influences of this configuration in the dynamics of the spaces occupied in the conurbated axis of the municipalities. The analysis of the data obtained allowed us to evaluate that the Contorno Norte facilitated the movement of business, the feasibility of the entry and exit of trucks, as well as the agility in deliveries. Both municipalities benefited from the work, in terms of favoring new ventures, although there are reports of intense traffic on between Maringá and Sarandi. The flow of vehicles on Colombo Avenue improved after the completion of the Contorno, despite complaints about the location of the work, positioned at the entrance / exit of two cities and in a large part of the junction of the Contorno Sul, which confuses the access to companies located on Avenida Colombo and favors the occurrence of traffic accidents. It was concluded that the work does not promote negative impacts for the enterprises and allowed for greater integration, not only between the cities in question, but the region.

Keywords: Conurbation. Urban planning. Economy. Paraná - North Region. 


\section{Introdução}

Na cidade, conforme apresenta Scott (1994), reúnem-se três espaços principais: o espaço da produção (fragmentado ou não); o espaço social (atividade residencial e da vida familiar); e o espaço da circulação (movimentos através da cidade). O que há em comum nesses aspectos, conforme Scott (1994), é a comutação diária dos trabalhadores entre o espaço da produção e o espaço social da cidade.

O apoio institucional que favorece a fragmentação das atividades econômicas pode variar de acordo com os objetivos e interesses para a geração de sistemas locais e regionais, que visam a instalação de equipamentos e da rede de apoio, para facilitar a ampliação dos negócios e dos lucros, integrando as mais diferentes disputas para a ocupação dos espaços intraurbanos.

Ao contextualizarmos as cidades de Maringá e Sarandi, localizadas na região Norte Central do estado do Paraná, é impossível não nos remetermos ao dinamismo econômico existente, já que a primeira apresenta tendências metropolitanas. Ambos os municípios foram projetados no âmbito do projeto de colonização da Companhia Melhoramentos do Norte do Paraná, CMNP, com propósitos diferentes, sendo que Maringá interliga os principais centros regionais do estado, os grandes centros nacionais e o Mercosul. Sua estrutura viária de ferrovia e de rodovias federais e estaduais, pela BR376 (que leva o nome de Avenida Colombo, em Maringá), possibilita ligações com a PR- 317 ao Sul do estado, ao sul de São Paulo e a Campo Mourão, além da PR-323 que dá acesso a Cianorte, Umuarama e ao Paraguai (VERCEZI, 2012).

A população estimada de Maringá (2018) foi de 417.010 habitantes (IPARDES, 2018), com mais de $98 \%$ da população na área urbana. Em Sarandi, a população estimada foi de 95.543 habitantes (2018) e o percentual de urbanização foi de 99,15\% (IPARDES, 2018). Problemas de tráfego na BR-376, que corta as cidades de Maringá e Sarandi, tornaram-se mais intensos ao longo das últimas décadas, com congestionamentos diários e inúmeros acidentes.

Uma solução prevista para a readequação da infraestrutura urbana foi desenvolvida pelo Departamento de Estradas e Rodagens do Estado do Paraná, DER-PR, 
pelo Departamento Nacional de Infraestrutura de Transportes, DNIT, e pela Prefeitura Municipal de Maringá, com um projeto que permitisse o desvio do tráfego pesado, contornando a cidade, e que visou possibilitar um escoamento mais rápido da produção e dos serviços.

Sabendo que o projeto de construção denominado PAC - Contorno Norte (2008) teve início na divisa de Maringá e Sarandi, e mediante os apontamentos expostos, discutimos quais foram os impactos da obra para ambos os municípios no trecho em que se conurbam¹. Como a Avenida Colombo (Maringá) é o objeto de estudo, procuramos problematizar a questão da edificação do Contorno Norte em relação à Avenida e, dessa maneira, responder ao seguinte questionamento: Quais foram as influências na dinâmica dos espaços ocupados, dos municípios de Maringá e Sarandi, sobretudo na Avenida Colombo, com a implantação da obra viária do PAC - Contorno Norte de Maringá?

O estudo evidencia transformações dadas por uma intervenção urbana que objetivou a melhor acomodação do tráfego local em uma das suas principais vias, a Avenida Colombo. Tendo como base a análise dos dados obtidos em entrevistas, identificamos alguns elementos quanto ao cumprimento dos objetivos do Contorno Norte e das ações do Estado para o processo de estruturação urbana e sua conurbação com Sarandi, bem como para demonstrar as percepções dos comerciantes e/ou transportadores em relação às mudanças favorecidas pelo Contorno Norte, no uso e ocupação do solo da Avenida Colombo, bem como quanto à acessibilidade à Maringá.

O presente estudo constitui-se dos seguintes procedimentos: revisão de literatura, consulta a relatórios de pesquisa, sites e reportagens pertinentes à temática, visitas in loco na área em questão, elaboração de mapas, através da captação de imagens do programa Google Earth, registros fotográficos e aplicação

\footnotetext{
${ }^{1}$ Conforme o IBGE (2016), a conurbação é uma forma de identificar arranjos, delimitando o traçado da área construída, uma vez que, quando duas cidades unem os seus tecidos urbanos, extravasam limites político-administrativos, nacionais e internacionais, e estabelecem fortes vínculos socioeconômicos. As cidades de municípios vizinhos costumam manter fortes relações entre si, mas nem sempre ocorre, entre elas, continuidade urbana. Nesse contexto, torna-se importante atualizar e estabelecer critérios para delinear formas espaciais que emergem de uma nova economia urbana, com seus novos conteúdos.
} 
de entrevistas semiestruturadas. As entrevistas são de caráter exploratório, ou seja, com uma metodologia qualitativa que, para Gil (2008), além de maior familiaridade com o problema, proporciona um embasamento teórico para o entendimento de situações que podem ser analisadas sob novo enfoque.

Em virtude da complexidade de coleta e análise dos dados, foram aplicadas dezessete entrevistas semiestruturadas de forma aleatória, correspondentes a mais de $70 \%$ dos participantes, constituídos pelos empresários de comércio e serviços do entorno da Avenida Colombo, no eixo conurbado (Maringá e Sarandi), cujo uso de solo se identifica em dois eixos: transporte e distribuição de cargas rodoviárias e revendas de automóveis - entre as cidades, representadas, respectivamente, por A e B, conforme a Figura 1. De acordo com Moreira (2004), os participantes são aqueles que fornecem uma descrição do fenômeno, possuindo, então, disponibilidade de tempo suficiente para as respostas. Assim, o que importa é a qualidade das entrevistas e, quando as respostas começam a se repetir, o ciclo deve se fechar.

Optou-se pela aplicação de entrevistas semiestruturadas por haver a liberdade de resposta do entrevistado e a possibilidade de levantamento de questões suplementares, quando não há algo previsto nas questões pré-determinadas. 
Figura 1 - Croqui de representação do uso do solo no eixo conurbado

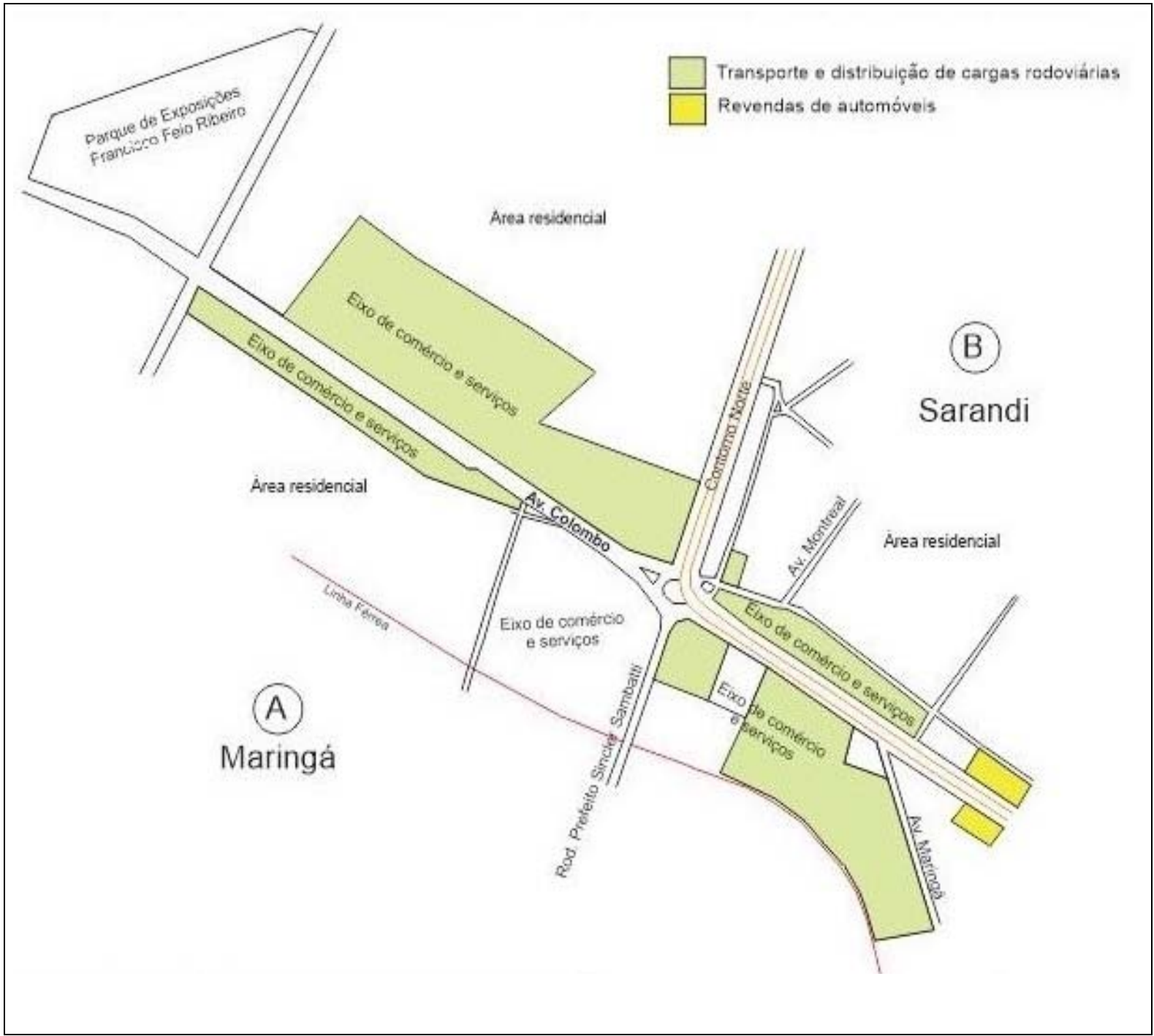

Fonte: Produzido pelos autores, 2018.

O trabalho foi assim estruturado: realizamos uma breve discussão dos elementos teóricos da pesquisa; em seguida, apresentamos discussões sobre a intervenção do Estado no eixo conurbado; e, na sequência, as transformações favorecidas pelo Contorno Norte e as percepções dos entrevistados. Por último, estão colocadas as considerações finais.

As discussões promovidas permitiram o avanço da compreensão da organização do espaço intraurbano e das atividades econômicas num eixo dinâmico do Paraná, 
contribuindo para avaliar a realização de uma obra de alto impacto e as políticas públicas para duas ou mais cidades.

\section{Os elementos teóricos da pesquisa}

A aproximação do estudo requer a discussão quanto à organização do espaço intraurbano e às atividades econômicas. Na organização dos espaços industriais e empresariais, são variadas as formas de interpretação sobre as interações existentes e as diferentes atividades e trocas, que permitem identificar as razões de permanência e sentido para a aglomeração de empresas e do conjunto das atividades setoriais. De qualquer modo, as atividades numa região e/ou numa cidade podem ser interpretadas sob diferentes escalas e para a realização de múltiplos recortes de tempo/espaço.

Nas argumentações de Scott (1994), a cidade é entendida por processos de aglomeração na dinâmica da divisão social do trabalho, como um mecanismo de base que reúne uma vasta quantidade de capital e de trabalho, sem esquecer dos inúmeros aspectos da vida social, cultural e política, que devem ser considerados para além dos aspectos econômicos.

Na Ciência Econômica Regional, por sua vez, as teorias clássicas são rediscutidas nos novos modelos e conhecê-las é importante para o entendimento da atual localização das áreas nas cidades. Todavia, para Amaral Filho, os últimos modelos, relacionam, ainda, as empresas e instituições públicas e:

[...] o forte processo de reciprocidade entre os mesmos, numa relação de concorrência e cooperação entre as empresas, e com uma lógica de funcionamento extrovertida, embora com raízes mais profundas com o território que acolhe tal aglomeração. Na realidade, não se trata mais de um aglomerado passivo de empresas, mas sim de um coletivo ativo de agentes públicos e privados atuando com um mesmo interesse, o de manter a dinâmica e a sustentabilidade do sistema produtivo local. (AMARAL FILHO, 2001, p. 277-278).

Para Polèse (1998), as estruturas econômicas, as tecnologias disponíveis e o lugar 
que ocupam frente à hierarquia urbana do país, bem como as preferências da população, são fatores que dimensionam uma cidade. Além disso, para esse autor, as economias de aglomeração podem ser agrupadas em dois eixos: economias de localização - economias internas, cujos ganhos das indústrias se atribuem ao desenvolvimento individual de cada empresa; e economias de urbanização - as economias externas às firmas e à indústria e que dependem do desenvolvimento geral.

A questão da atuação do Estado e também de promotores imobiliários, principalmente no caso de Maringá, faz-se na organização dos espaços para a nítida expansão de negócios. Assim, é intento do setor público intervir, de modo a controlar o solo urbano, impedindo ocupações, o que faz do zoneamento urbano uma ferramenta para regular as utilizações do solo, enquanto reflexo do planejamento, embora haja a pressão dos chamados stakeholders', cabendo, assim, à autoridade local, garantir o beneficiamento da coletividade. Entretanto, alterações nas legislações, implantações de obras viárias e equipamentos urbanos acabam por estabelecer áreas privilegiadas para determinados grupos, cujos investimentos são maiores em áreas de interesse.

Para Villaça (1997), o controle do Estado se faz sobre a localização da infraestrutura urbana e de seus aparelhos, e sobre a legislação de uso e ocupação do solo, enquanto o controle do mercado imobiliário se faz nos privilégios das classes dominantes, "no local onde elas desejam" (VILLAÇA, 1997, p. 8).

Seguindo as observações de Wittmann e Dotto (2006), o aglomerado de empresas se desenvolve a partir de determinações inerentes ao desenvolvimento da região, acompanha o contexto social, político, econômico e tecnológico, havendo certo relacionamento entre si; mas sem, necessariamente, coordenação ou estrutura, que permitem sustentação organizacional. Apesar de tais discussões, Brandão (2004) contextualiza os temas urbanos e regionais para a convergência de interesses dos municípios nas últimas décadas. Enfatiza Brandão:

\footnotetext{
${ }^{2}$ Comentam Teixeira e Moraes (2013) que a noção do termo stakeholder é abrangente. Para os autores "na teoria e na prática das organizações, sinaliza as limitações para a legitimação pela organização dos grupos de interesse, e isso se constitui um desafio na identificação destes stakeholders que se formam ao longo da trajetória histórica da empresa" (TEIXEIRA; SOARES, 2013, p. 212).
} 
A construção de uma visão crítica passa, a nosso ver, pelo reconhecimento da impossibilidade de uma teoria geral e abstrata (pronta e acabada) da problemática regional e urbana, trazendo tal objeto para o lugar de onde ele nunca poderia ter saído: o âmbito da discussão estrutural do processo de desenvolvimento. Ou seja, cabe aproximar-se recorrentemente da análise da dimensão espacial do processo de desenvolvimento - subdesenvolvimento. (BRANDÃO, 2004, p. 59).

A diversidade dos acontecimentos e das mudanças na organização do espaço regional e intraurbano, ora pelos nexos com uma economia global, ora pela predominância com laços para uma economia regional/local, em repetidos movimentos, que buscam a manutenção das atividades, permite um contínuo esforço da pesquisa empírica para promover a compreensão da urbanização e dos aspectos que correspondem ao entendimento de como os grupos, sujeitos e o Estado participam das estratégias e das decisões que implicam na permanência e na instalação de aglomerados empresariais.

Nesse caso, do ponto de vista espacial e político, "o aglomerado de empresas visa, também, aumentar o desenvolvimento local e regional, criando ambientes propícios para a futura formação de Arranjos Produtivos Locais (APLs) e Sistemas Locais de Produção (SLPs)." (WITTMANN; DOTTO, 2006, p. 23).

A identificação de mudanças estruturais na área urbana, a partir da intervenção pública e considerando a escala local, estabelece maneiras de se identificar como e quais razões fazem grupos econômicos manterem-se instalados e à procura dos novos espaços, que permitem abandonar estratégias que serviram para a escolha da localização anterior ou mesmo para a manutenção das propriedades locais marcantes para uma ou mais cidades. Sob tal foco, Scott (1994), no que se refere às estruturas institucionais específicas da aglomeração, ressalta a importância do planejamento urbano, pois "fornece os meios coletivos de governança indispensáveis para atacar as múltiplas derrocadas e desintegrações, verificadas no sistema urbano, para assegurar o seu funcionamento contínuo." (SCOTT, 1994, p. 68). 
Scott e Stoper (2018) observam diferentes tipos de abordagens metodológicas e linhas de investigação para a pesquisa urbana na literatura, desde o início do século XX até o presente. Destacam-se, conforme os autores, nesse âmbito, as interpretações sobre a ascensão de um sistema urbano global e sobre os efeitos da globalização na estrutura interna das cidades, e também a tendência para a reconceitualização de preocupações mais antigas sobre política urbana e governança. Noutro prisma, Scott e Stoper (2018) reforçam que as cidades estão fortemente, e cada vez mais, interligadas entre si em redes relacionais e não pode haver um limite rígido e absoluto entre qualquer cidade e o restante do espaço geográfico.

Das variadas descrições que indicam as possibilidades dos estudos urbanos apresentados por Scott e Stoper (2018), ressalta-se, na opinião dos autores, que:

os estudos urbanos são suscetíveis a descontinuidades e disjunções endêmicas cada vez maiores nos quadros conceituais, nas questões e nas metodologias que dominam a pesquisa. Isso não é inteiramente surpreendente, dada a complexidade das causas da urbanização e a natureza multifacetada do urbano. Da mesma forma, a "questão urbana", no sentido de pesquisa que está ligada a objetivos políticos [politics] ou preocupações políticas [policy], parece mudar de direção a cada nova geração de estudiosos do urbano. (SCOTT; STOPER, 2018, p. 9).

O reconhecimento da aglomeração de empresas e das atividades associadas às mudanças promovidas pela intervenção pública, passa a ser entendido como uma das mais variadas formas de entender planos e estratégias políticas e permite ampliar o debate do desenvolvimento urbano num período caracterizado pela reestruturação urbana ou das cidades, dentro do contexto da globalização, em que a cidade passa a ser vista como uma mercadoria (VAINER, 2000).

As iniciativas do poder público e num eixo de metropolização, como foi o caso da pesquisa, não só redirecionam investimentos para uma ou mais cidades, como as intervenções pontuais podem antecipar ou elevar níveis de desigualdade da estrutura disponível, a escolha da localização de empresas e dos interesses para futuros 
investimentos.

Scott e Stoper (2018, p. 13) acentuam que "a expansão econômica e a urbanização devem, portanto, ser devidamente compreendidas como sendo interligadas em uma relação recursiva, dependente da trajetória ao longo do tempo, com seu ponto crítico de articulação focado em processos de aglomeração". Nesse caso, os propósitos da disposição das empresas e dos equipamentos e suportes disponíveis podem antecipar o interesse para novos processos de concentração, como também elevar o nível das discussões e dos mecanismos para a reorientação das leis municipais e das políticas públicas.

O fato da instalação de uma obra de grande impacto localizar-se entre duas cidades que apresentam contínuo crescimento urbano (Maringá e Sarandi), requer uma abordagem mais aprofundada de quais efeitos e propostas podem ser identificados e aprimorados, com o fim de permitir a avaliação e o acompanhamento de novas formulações da política urbana e das reivindicações dos grupos econômicos.

Na presente pesquisa, o comportamento e a percepção dos responsáveis pelas organizações são identificados na abrangência dos elementos dispostos pela ação do Estado e dos interesses individuais pela localização.

\section{A intervenção do Estado no eixo conurbado e a conurbação entre} Maringá e Sarandi

Na região norte central paranaense, Maringá configura-se como polo de atração para cidades próximas, de menor porte, principalmente Sarandi (Figura 2). Desse modo, a dinâmica do extravasamento da cidade polo a outros centros dita a complexidade da estruturação urbanística, configura o que se denomina como aglomeração urbana (MOURA et al. 2009 apud VERCEZI, 2012).

No plano urbanístico de Maringá (Figura 3), a Avenida Colombo, objeto de estudo, era a principal via de acesso a essa e às outras cidades, como Londrina, São Paulo, Paranavaí, Campo Mourão, o que limitava o plano inicial ao norte, como também 
causava um entroncamento de transportes rodoviário, ferroviário e aéreo. Toda a infraestrutura desponta de Maringá, a qual, há algumas décadas, apresentava uma economia voltada para o processo agroindustrial, com grande influência, não só no estado do Paraná, mas também em regiões de Dourados-MS, de Presidente Prudente e Assis-SP, e do Paraguai, devido à atuação aduaneira e ao porto seco (IPEA, 2000).

Figura 2 - Recorte espacial de Maringá e Sarandi (PR)

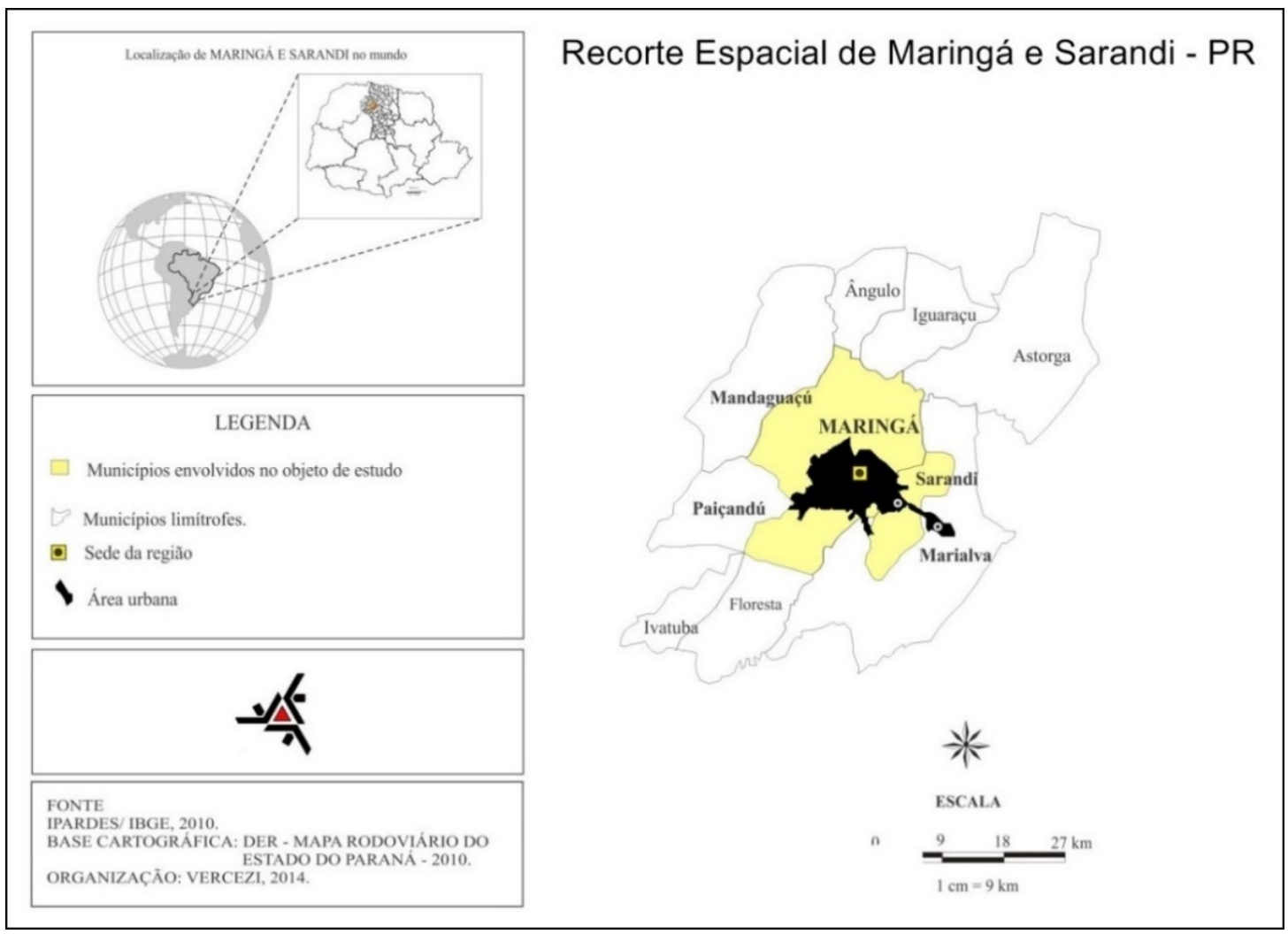

Fonte: Longen, 2014. 
Figura 3 - Plano urbanístico de Maringá em 1945

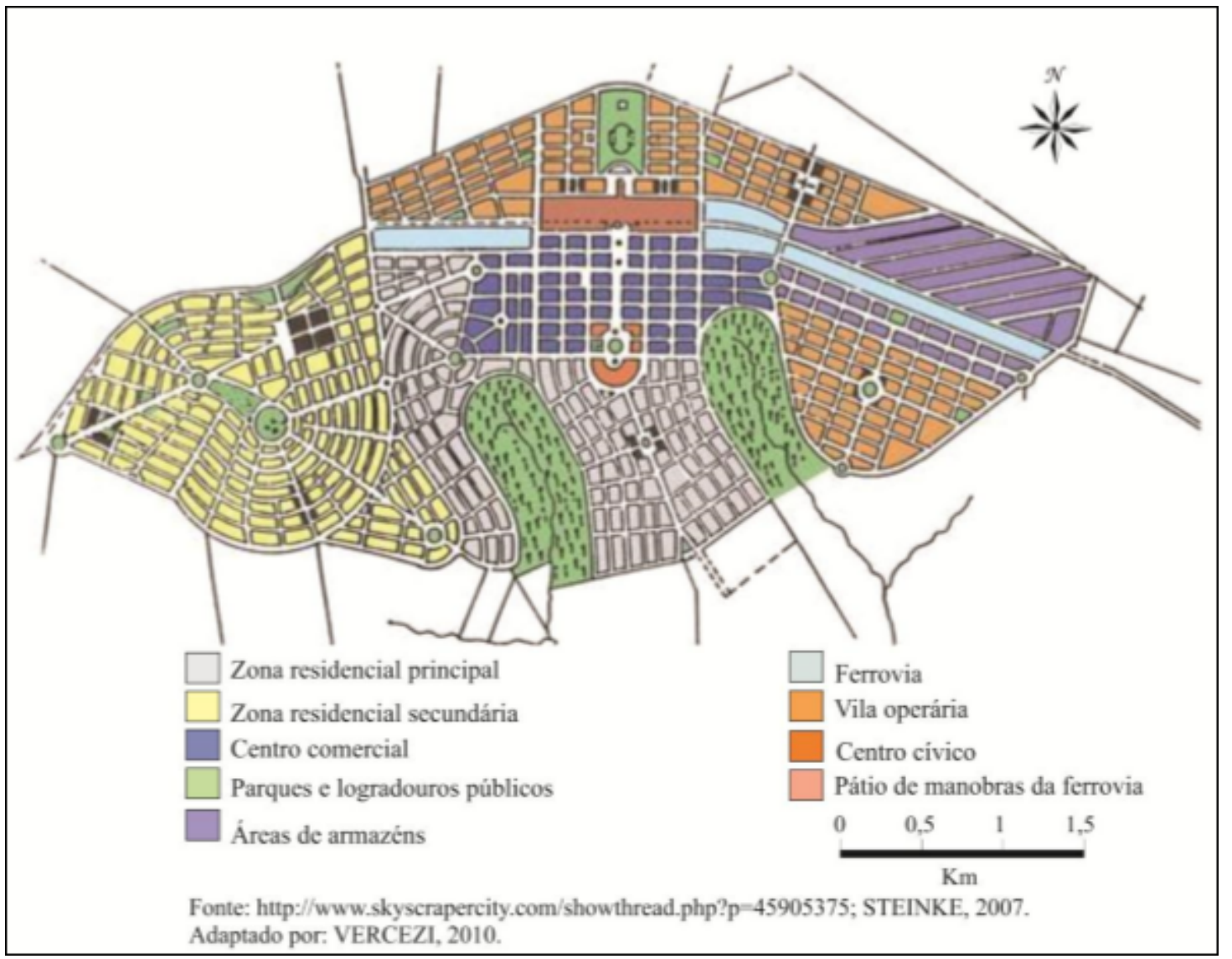

Fonte: Vercezi, 2012.

É na década de 1980, com o crescimento acelerado de Maringá e a substituição da cultura cafeeira pelos grãos para exportação, que a cidade se torna um centro atacadista de insumos agrícolas modernos, elaborado pelo Plano de Diretrizes Viárias, de Nildo Ribeiro da Rocha, que reconfigurava a cidade e as novas ocupações, além das áreas delimitadas inicialmente, e adotava “[...] uma malha retilínea, com o intuito de conciliar os interesses imobiliários e as facilidades de locomoção e de deslocamento na cidade, e entre as cidades da Região Metropolitana de Maringá" (RODRIGUES, et al. 2011, p. 05). As áreas cerealistas localizadas próximas à ferrovia perderam sua função e foram substituídas por supermercados atacadistas, instalações industriais e depósitos para transportadoras, ao longo de avenidas principais, como a Colombo, conforme o atual uso do espaço urbano se mostra. Na medida em que a expansão da malha urbana 
continua até seus entornos, estruturam-se os municípios periféricos.

Desse modo, no que se refere aos Planos Diretores de Maringá, de acordo com Rodrigues:

\begin{abstract}
Quando [...] foram elaborados e passaram a legislar sobre o zoneamento, o poder público consolidou o controle do desenvolvimento urbano, pois são as leis de zoneamento que determinaram a configuração da cidade em sequência ao determinado no projeto da CMNP. A concentração do crescimento urbano no âmbito do planejamento contou ainda com a participação do setor imobiliário na produção da legislação urbanística, seja através de influência no legislativo ou no próprio poder executivo. (RODRIGUES, 2004, p. 229).
\end{abstract}

Pode-se dizer que os planos diretores de Maringá influenciaram cidades vizinhas, pois o poder público municipal e o mercado imobiliário tiveram, desde o início, um caráter determinante, principalmente no aspecto de segregação socioespacial, tendo em vista que indivíduos do governo municipal também atuavam no mercado imobiliário, mais especificamente para aprovar os projetos que interessavam à companhia, inclusive com apoio do legislativo. Assim, a cidade se reproduziu a partir do modelo núcleo periferia (RODRIGUES, 2004).

A configuração da conurbação urbana de Maringá, sobretudo com Sarandi, estrutura-se, como já mencionado, no eixo rodoviário da BR-376, que leva o nome de Avenida Colombo (Figura 4) e teve início quando a primeira, através de sua política habitacional, coibia ocupações de baixa renda, que passaram a ser transferidas para as cidades de Sarandi e Paiçandu, por meio de uma população que vinha em busca da alta oferta de trabalho e que não suportou os altos custos de habitação, bens de consumo e serviços urbanos. Com a substituiçãa da cultura cafeeira pela mecanização da agricultura (soja e trigo), a microrregião de Maringá foi a terceira que mais cresceu, dentre os principais polos industriais do país, de 1970 a 1985 (DINIZ, 1995 apud BORGES; ROCHA, 2009).

O recorte espacial no estudo, definido pelo novo modelo de Divisão Regional, do Instituto Brasileiro de Geografia e Estatística (IBGE, 2017), que se constitui em 
Regiões Geográficas Intermediárias - organização e articulação das regiões geográficas imediatas, através de um polo de hierarquia superior - e Regiões Geográficas Imediatas - estruturadas a partir de centros urbanos próximos para suprir as necessidades básicas das populações (antes, unidades mesorregionais e microrregionais), configura o Estado do Paraná em seis regiões geográficas intermediárias, que contemplam vinte e nove regiões geográficas imediatas (IBGE, 2017). Nesse contexto, incorporando a Região Geográfica Intermediária de Maringá, esta se evidencia como cidade imediata, como um polo, concentrada e objetivada para a oferta de equipamentos, bens e serviços, tais como: setor privado especializado; redes de supermercados e hipermercados; veículos; atacado de vestuário e têxtil; sistema bancário; estruturação e consolidação de polo tecnológico; entre outros, cuja influência sobre Sarandi é contínua, pois esta se mostra com funções limitadas 3 em decorrência, justamente, da força política e econômica de Maringá sobre Sarandi (VERCEZI, 2012), que pertence à Região Geográfica Intermediária de Maringá.

Com o elevado crescimento habitacional, a região não atendeu a demanda por empregos e muitos migraram para outras regiões do país. A mobilidade populacional, que aconteceu de forma caótica, ocasionou que parte dos que deixaram o campo, nas décadas de 1960, 1970 e 1980, dirigiram-se para as cidades polos regionais, instaurando um processo de periferização externa, principalmente no eixo Maringá-Londrina (Figura 4).

\footnotetext{
3 Vide o planejamento realizado pela Companhia Melhoramentos Norte do Paraná, que criou cidades distantes umas das outras, a cada $15 \mathrm{~km}$, em média, sendo que as vias de circulação proporcionaram uma interligação entre diversas localidades do território, facilitando, assim, a estruturação do aglomerado de Maringá, reforçado pelo êxodo rural.
} 
Figura 4 - Extravasamento de ocupação da cidade polo

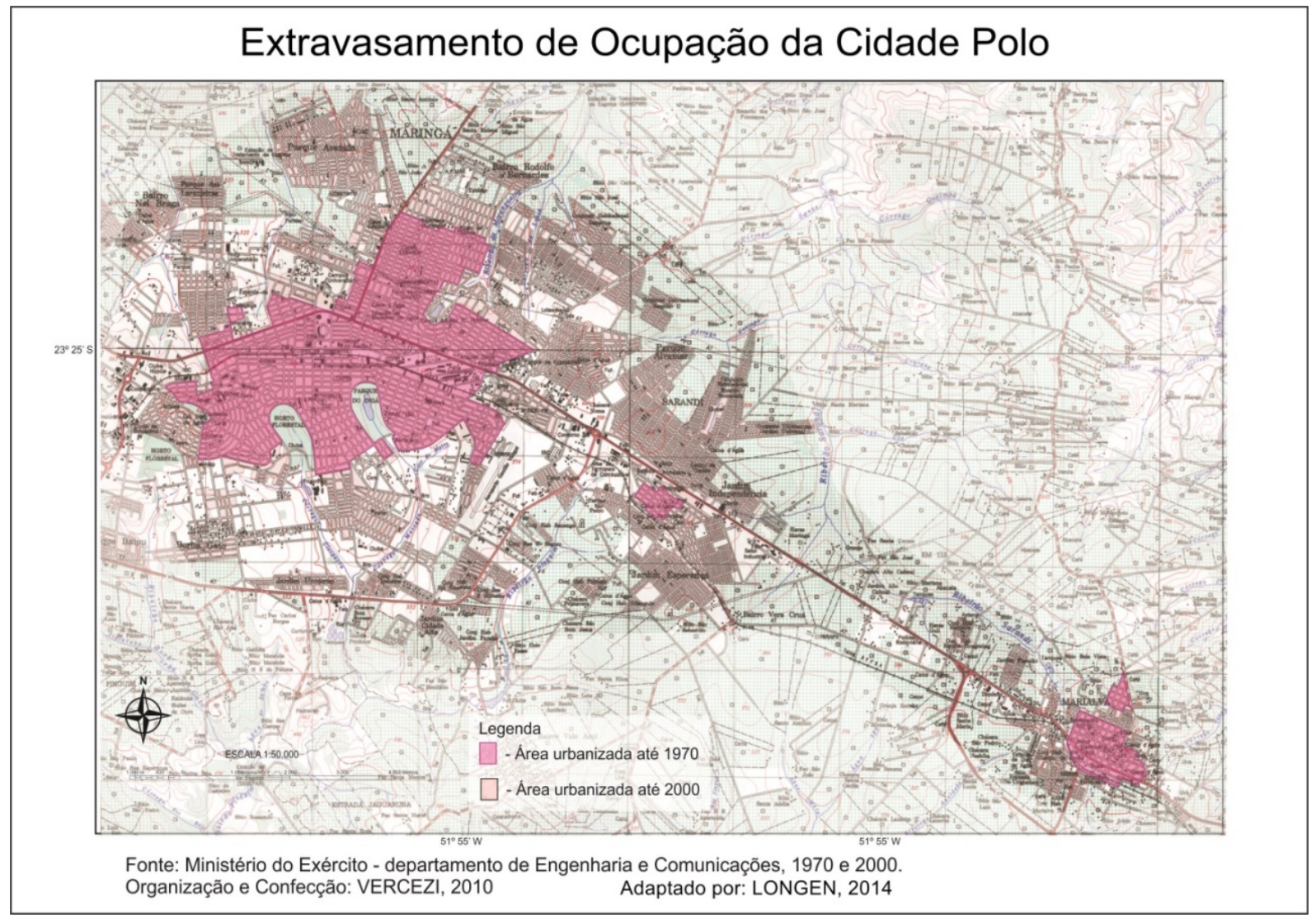

Fonte: Vercezi, 2012.

Para Rodrigues (2004, p. 97), "[...] iniciou-se o extravasamento da mancha urbana do polo metropolitano sobre os municípios limítrofes, Sarandi e Paiçandu, a leste e a oeste de Maringá, respectivamente, num nítido processo de conurbação entre as três áreas fronteiriças".

Desse modo, Sarandi, surgida em 1935, como patrimônio para servir de entreposto comercial e de abastecimento aos produtores rurais entre Maringá e Marialva, e fundada pela Companhia de Terras Norte do Paraná em maio de 1947, ), cresceu 4,52\%, cerca de duas vezes mais que Maringá (2,06\%) (BORGES; ROCHA, 2009), e apresenta dois desdobramentos: a) viabilização da inserção de mão de obra demandada por indústrias e outros; b) incentivo às loteadoras maringaenses para atuarem próximas ao centro dinâmico, devido à fragilidade de legislação urbanística de Sarandi, o que proporcionou uma mínima infraestrutura. 
Assim, estruturada no mesmo processo que Maringá, a questão da conurbação se acentuou a partir da década de 1990.

\subsection{A implantação do contorno Norte: idealização e concretização}

A implantação do contorno norte resultou de intensas discussões, devido a diários congestionamentos e acidentes no eixo rodoviário, caracterizando o trecho entre Maringá e Sarandi como o mais perigoso do estado, de acordo com dados da Polícia Rodoviária Federal (FRANCO, 2014). Para a Prefeitura Municipal e órgãos competentes, a Avenida Colombo precisava ser desafogada e, para isso, foi elaborado o projeto denominado PAC - Contorno Norte de Maringá, que foi implementado com o objetivo de aliviar o tráfego pesado de caminhões das Avenidas Morangueira e Colombo, duas principais vias da cidade (Ministério da Infraestrutura, 2014) (Figuras 5 e 6).

Embora a edificação tenha seu traçado definido na década de 1990, suas obras só tiveram início em 2008, com uma adequação do projeto pela Prefeitura Municipal de Maringá, tornando-o uma "via expressa”, sem interferir no sistema viário local, cujo término ocorreu em 2013, sendo considerada a maior obra pública de Maringá (RODRIGUES et al., 2011). A obra ainda ficou parada por um ano, devido a suspeitas de superfaturamento. A inauguração ocorreu em 10 de janeiro de 2014, com a presença da Ministra-Chefe da Casa Civil, Gleisi Hoffmann, e do Ministro dos Transportes, César Borges, àquela época (MINISTÉRIO DA INFRAESTRUTURA, 2014).

O Contorno Norte de Maringá se faz por uma pista dupla, com 17,6 quilômetros de extensão, que liga, a leste, o trevo na divisa entre as cidades de Maringá e Sarandi entroncamento com o Contorno Sul - e, a oeste, com o trevo da Coca-Cola, onde está o entroncamento com a Avenida Sabiá e conta com 13 viadutos, 12 passarelas para pedestres, três pontes sobre os ribeirões Maringá, Mandacaru e Morangueiro, e uma trincheira.

Uma importante observação associa-se à restrição de veículos pesados na Avenida Morangueira, referente ao cruzamento com a Avenida Colombo e ao viaduto do Contorno Norte, que passou a funcionar em $1^{\circ}$ de agosto do ano de inauguração, 
para que os motoristas passem pelo anel viário do Contorno Norte, já que o fluxo urbano não diminuiu como se esperava no local (ROSSATTO, 2014).

Figura 5 - Localização do Contorno Norte sobre o Google Earth (2014)

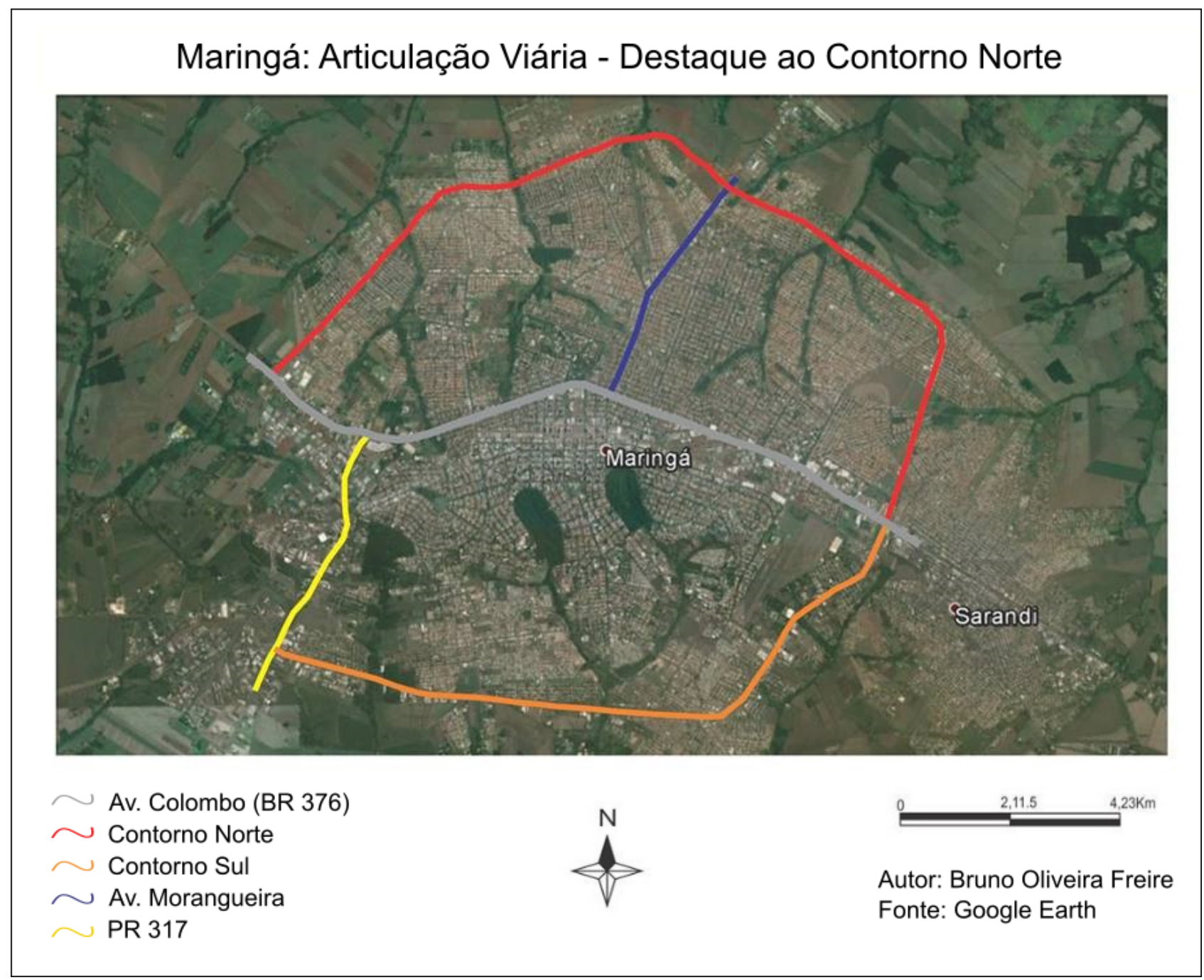

Fonte: Rossatto, 2014

Com um investimento de $\mathrm{R} \$ 4_{112}$ milhões, a obra foi executada pela Empreiteira Sanches Tripoloni, com recursos do Plano de Aceleração do Crescimento, PAC (MINISTÉRIO DA INFRAESTRUTURA, 2014). O Departamento Nacional de Infraestrutura de Transporte, DNIT, órgão responsável pela execução da obra, avaliou o contorno como fundamental para o contexto viário local e regional, já que 
desvia o fluxo pesado da área central e trouxe, além disso, inúmeros benefícios a Maringá e região, tais como: separação do tráfego rodoviário de média e longa distância do tráfego local urbano; fluidez do tráfego, minimizando o índice de acidentes dos usuários da cidade, como, também, dos viajantes que passam por ela; diminuição do tempo de viagem, principalmente em veículos pesados e que transportam cargas; redução da emissão de poluentes e ruídos no trecho em que a BR-376/PR corta a cidade; entre outros.

Apesar do objetivo da obra ter sido a acomodação do tráfego urbano, o Contorno Norte não visa o bem-estar da população em seu entorno, que percebe seus direitos à cidade negados, pois o Contorno é uma barreira física para segmentar os bairros $^{4}$, conforme mostrou estudo realizado pelo Observatório das Metrópoles, em $2011^{5}$.

Figura 6 - Mosaico de fotos do Contorno Norte de Maringá

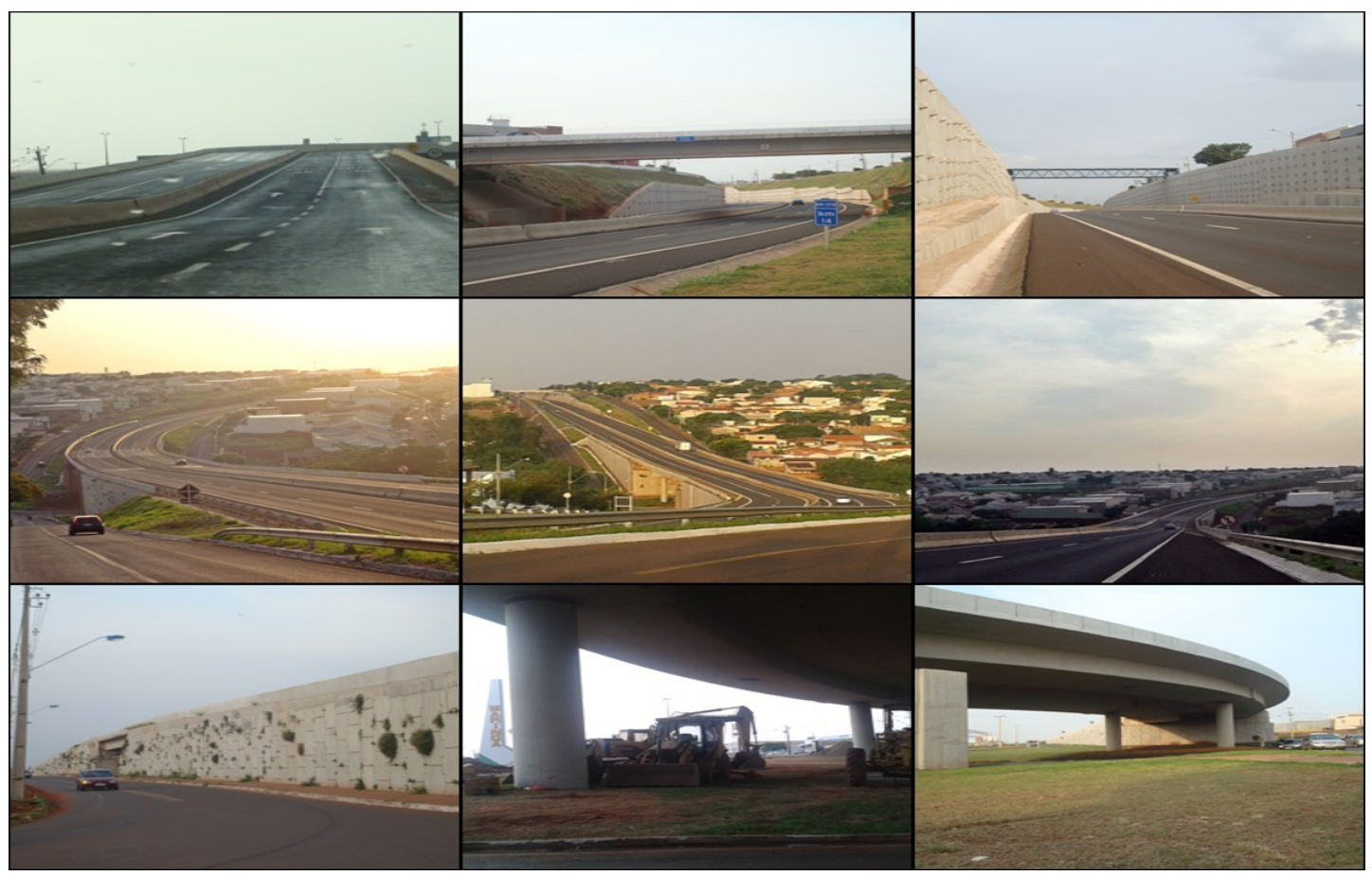

Fonte: Rossatto, 2014.

\footnotetext{
4 Tendo em vista que o projeto foi desenhado há vinte anos, quando a malha urbana não era tão densa, e que, em vez de contornar a cidade, como seu próprio nome indica, a edificação separa os setores censitários de Maringá.

${ }^{5}$ Ver Rodrigues, et al (2011a).
} 


\section{As transformações pelo Contorno Norte e as percepções dos} entrevistados

As questões contidas nas entrevistas semiestruturadas visaram verificar os seguintes aspectos, divididos em duas linhas: 1) o movimento dos negócios com a implantação do Contorno Norte e os impactos e/ou transformações ocasionados para as empresas; 2 ) o surgimento de novos empreendimentos com a finalização da obra, e o favorecimento da integração entre Maringá e Sarandi, seguindo a linha de percepção dos entrevistados. Das empresas localizadas e participantes, apenas duas foram instaladas após a finalização do Contorno.

Seguindo a ordem das questões do roteiro, quando perguntados se, com a finalização da obra, houve maior facilidade, ampliação ou dificuldade na movimentação de negócios da empresa, 65\% dos entrevistados disseram que esse aspecto melhorou, conforme demonstra a Figura 7.

Figura 7 - Movimentação de negócios das empresas

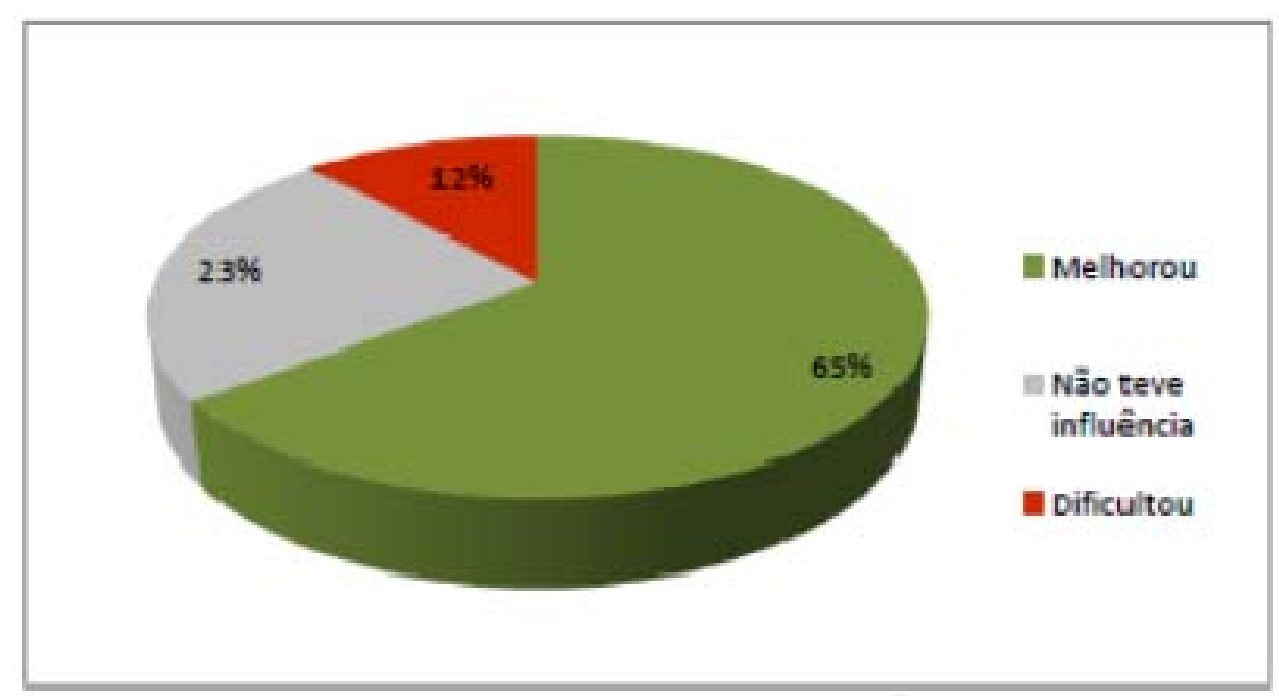

Fonte: Pesquisa de campo no eixo conurbado de Maringá e Sarandi, 2018.

A maioria dos entrevistados disse, também, haver uma melhora, para suas empresas, na viabilização da entrada de caminhões e na agilidade de entrega de mercadorias, conforme se observa no primeiro e segundo depoimentos transcritos a 
seguir. Entretanto, as empresas que disseram haver uma dificuldade maior quanto à movimentação de negócios, concordaram que houve melhora no fluxo de carros da Avenida, transcrita no terceiro depoimento:

[D1] Ah, acho que a parte de, assim, entrega de mercadoria... a gente entrega bastante mercadoria pro lado de Astorga... acho que agilizou pelo acesso mais rápido né... porque, antigamente, você tinha o que, a Morangueira, a Colombo bastante congestionada né, então, nessa parte de entrega de mercadoria, de logística, pra nós melhorou.

[D2] Muito, muito, muito... porque a gente tem uma carreta que vem de Presidente Prudente. Ela vinha pela Morangueira. Quando ela vinha pela Morangueira, era um transtorno pra atravessar a Colombo depois das sete da manhã... então era um caos... chegava aqui sempre... até chegar em Maringá era um x, depois que chegava em Maringá, você podia colocar mais quase uma hora pra ela chegar até a empresa.

[D3] Pra empresa dificultou um pouco, porque o caminhão que antigamente passava aqui na frente, hoje, a maioria não passa né! Assim, pra empresa deu uma piorada... agora com o fluxo de caminhão versus pessoal, melhorou com certeza!

Quanto aos questionados sobre o favorecimento ou não de novos empreendimentos, a maioria dos entrevistados concordou que ambos os municípios em questão se beneficiaram da obra do Contorno, como aponta a Figura 8:

Figura 8 - Favorecimento de novos empreendimentos para Maringá, Sarandi e ambas

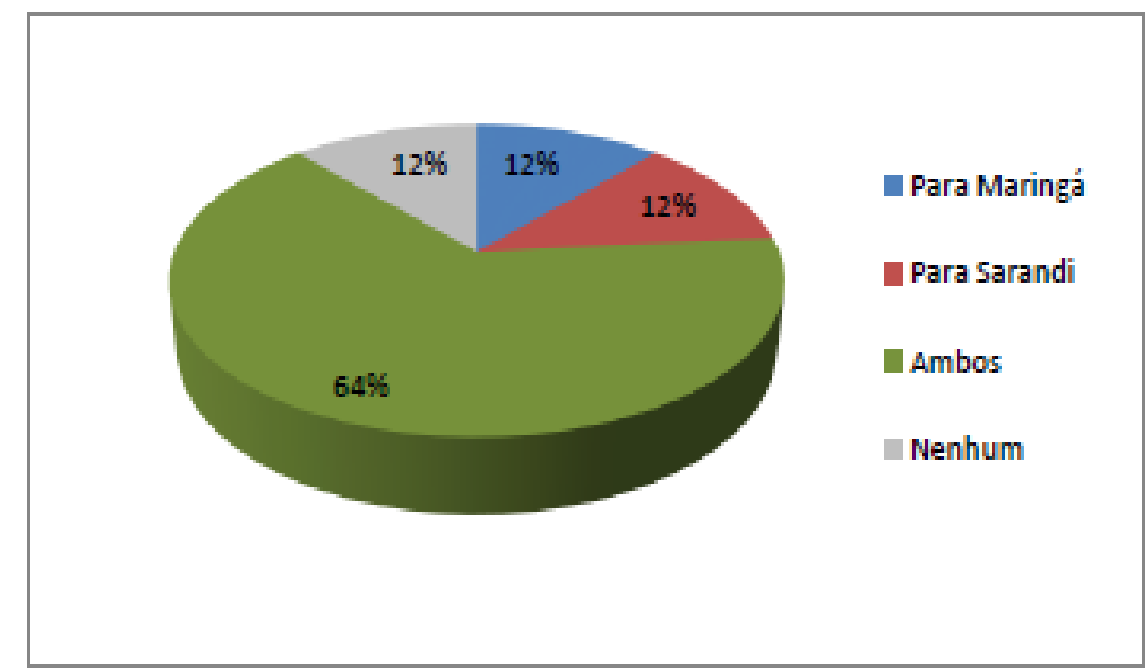

Fonte: Pesquisa de campo no eixo conurbado de Maringá e Sarandi, 2018. 
Embora os entrevistados concordem que, em geral, o trânsito ao longo da Avenida melhorou, algumas opiniões, como pode ser visto na Figura 8, negam a ocorrência do favorecimento de novos empreendimentos, justamente pela via do Contorno ter o objetivo de contornar a cidade, como apontam as seguintes transcrições:

[D4] Na verdade, o contorno norte, ele é uma via de... você não tem acesso a ele né... é uma via... é uma rodovia perdida né, então, favoreceu, acho que o trânsito, quer dizer, tirou muito trânsito aqui da Colombo, mas quanto a isso, prejudicou para os comércios aqui da Colombo, que os caminhões passando ou não é... tanto caminhão, carros né... você teria melhor rendimento no comércio... aqui, agora tá desviando...

[D5] [...] tem vários barracão fechado, por conta do contorno norte, que seria hoje... vamo supor, minha empresa é aqui, mas poderia ser lá [...] porque lá, os barracões hoje lá... é... custa bem mais barato do que eu pago aqui, mas não tem nenhum tipo de acesso que passa na rodovia pra entrar nos comércio, então pode notar [...] anda nas beiradas pra você ver, quantas empresas, de fora a fora fechadas, empreendimentos, empresas em desenvolvimento, igual a minha que não tem como... no meu caso, eu tenho, eu preciso ser visto [...] se lá fosse igual aqui, eu não taria aqui, taria lá, igual outras empresas né.

Sobre possíveis impactos da obra para as empresas, 59\% dos entrevistados disseram que não houve impactos, enquanto 35\% disseram haver algum tipo, como aponta a Figura 9.

Figura 9 - As transformações/impactos da obra para as empresas

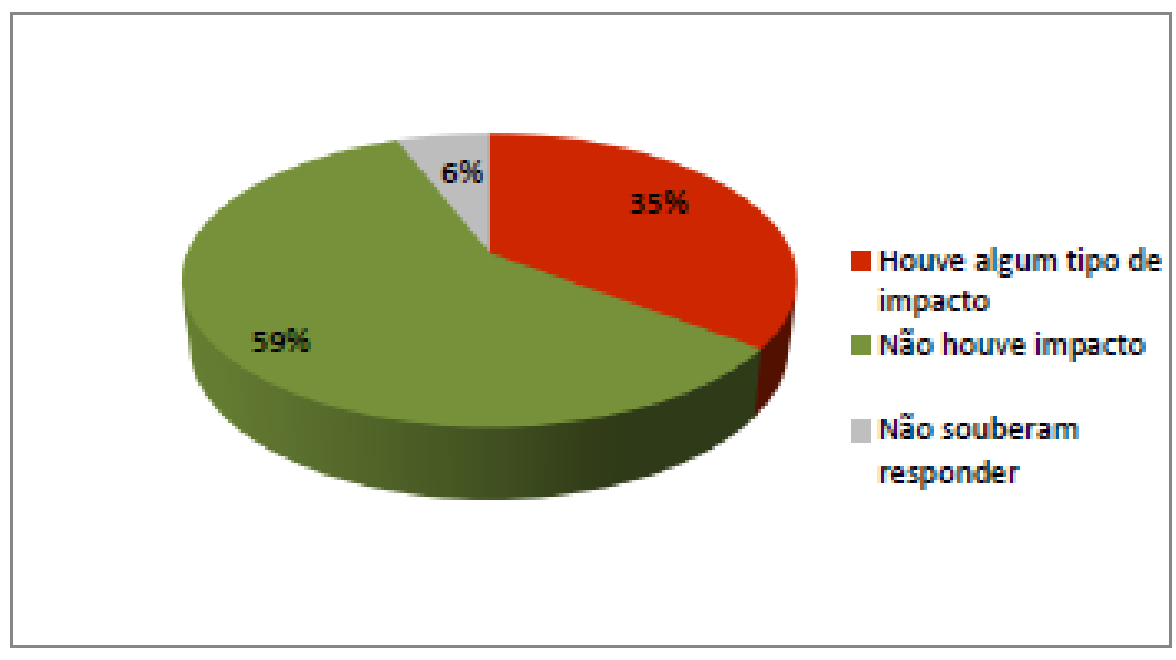

Fonte: Pesquisa de campo no eixo conurbado de Maringá e Sarandi, 2018 
É importante ressaltar que todos os entrevistados subentenderam a palavra “impacto" como algo negativo; portanto, os que responderam que não houve nenhum tipo de impacto, também disseram haver maior rapidez nas entregas. O desvio do tráfego de caminhões da Avenida Colombo, o trânsito no local de iniciação do viaduto, as reclamações de clientes em relação ao acesso às empresas, que se tornou dificultado e/ou confuso, rachaduras na estrutura dos estabelecimentos, a perda de clientes pelos transtornos durante a execução da obra, bem como a falta de locais para estacionamentos, foram os problemas relatados.

[D6] ... A única influência que nós temos hoje é a questão da acessibilidade... que hoje, como nós só temos uma saída... é... pro contorno, vamos dizer assim, só a paralela e uma saída, então, complica um pouco, principalmente nas entregas.

Houve também algumas reclamações quanto à obra em si, localização, sinalização e o número de acidentes ocasionados pelo Contorno Norte:

[D7] Praticidade e rapidez. Pra nós o impacto foi esse né. Agora, o ponto negativo que tá acontecendo pra gente é a marginal aqui ó... essa marginal... por diversas coisas, trânsito, principalmente, mas... acidentes né?! [...] Beirando os viadutos ali né, mas... então não sei o que que falta e... foi feito a passarela aqui na marginal, pra atravessar a Colombo aqui, só que, nessa passarela [...] você fez a travessia da passarela, você vai pra onde? Não tem uma faixa. Não tem uma calçada pro pedestre passar! E quando chove?! Que ali vira só água?! O pedestre sai da passarela... pra onde vai? Não tem pra onde vai. Então, assim, talvez não tenha muita ligação com o Contorno Norte, porque já faz parte da Colombo isso né, mas... de certa forma, o único acesso que você tem, se não for a passarela, acaba sendo o viaduto lá embaixo... não tem outro, porque eles fecharam tudo aqui.

[D8] [...] a obra é muito mal executada [...] é um perigo andar ali... ali, na verdade não é um contorno norte, é um contorno da morte [...] não tem nenhuma sinalização que é prevista por lei de trânsito e outra, é... ali é um... na verdade, ali é um, vamo falar assim, é... ali é um esgoto, porque só tem uma entrada e uma saída né, é tudo ali, então ali é um esgoto, por isso é pouco movimentado ali. Ali daria certo assim, se tivesse igual o contorno sul... o contorno sul, aqui pra nós, ele tem toda uma ligação com os bairros.

[D9] Tinham que viabilizar não só pra população de Sarandi como de Maringá. Mas tinha que ser um negócio funcional e não foi funcional, não tá sendo funcional. Por que que não tá sendo? Porque ele ficou um 
labirinto [...] então, o que que acontece, você cai aqui dentro do Contorno Norte, você vai sair lá na Morangueira ou lá na saída de Paranavaí. Aí, mas vamos supor que eu quero ter acesso ao Requião pelo Contorno Norte, já não tenho... aí, eu quero ter acesso ao Alvorada, eu não tenho! Pelo Contorno Norte não. Aí seria uma via rápida e de acesso rápido pros moradores de Sarandi e pros moradores de Maringá né [...] Hoje, nós cai dentro do Contorno Norte, pra nós ter que voltar, nós tem que sair na Morangueira, aí desce beirando pela Morangueira... ah, rapaz... pra sair aqui no fundo do... como que fala esse jardim aqui... do Alvorada, você entendeu?! Então, quem tá em Maringá né... já, nem conhece o Contorno Norte, quem mora dentro de Maringá não conhece o Contorno Norte, porque nunca usou e nem nunca vai usar...

É importante deixar claro que, embora tenha sido relatado que o Contorno não é funcional, no sentido de proporcionar ligações com os bairros que "corta", a estrutura foi adaptada para funcionar como uma via expressa, para que não interferisse no trânsito local, e é justamente por isso que moradores dos bairros do entorno reclamam, já que o acesso às outras áreas da cidade foi dificultado. É importante salientar, também, que não cabe a este estudo investigar os impactos sobre os setores censitários que foram cortados pela obra.

A última pergunta do roteiro se referiu à opinião de cada entrevistado sobre o favorecimento ou não da integração entre Maringá e Sarandi com a obra, em que 65\% disseram haver integração entre as cidades e 35\% disseram não haver (Figura 10).

Figura 10 - Favorecimento ou não da integração entre Maringá e Sarandi

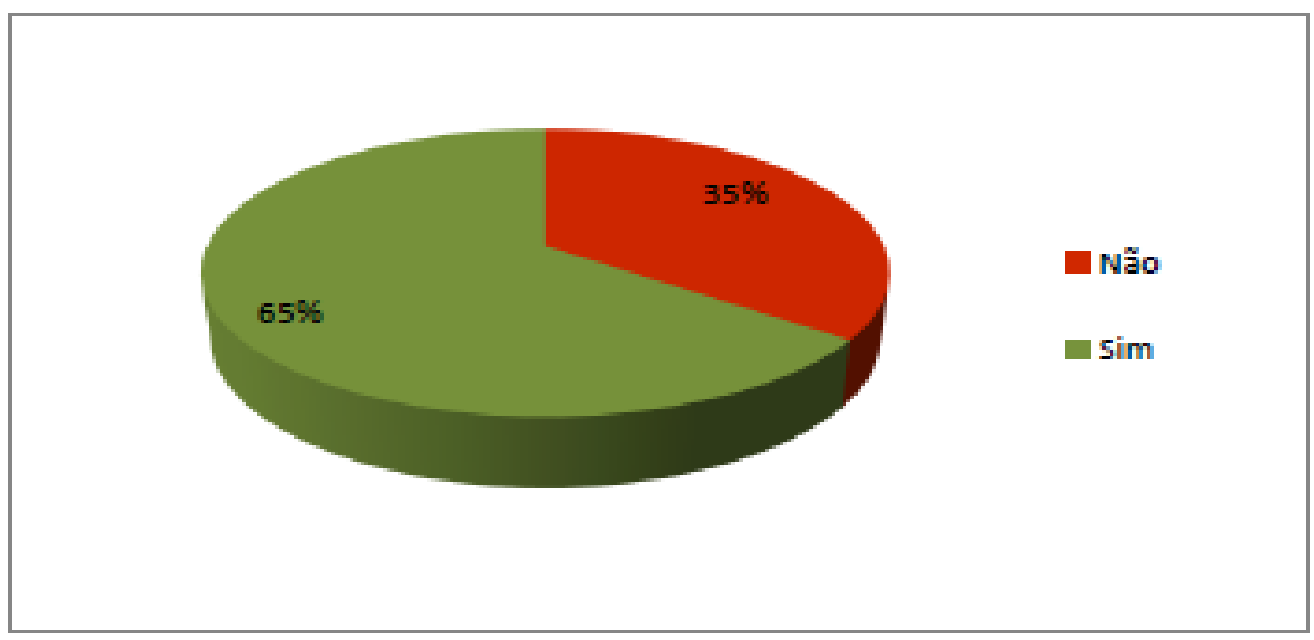

Fonte: Pesquisa de campo no eixo conurbado de Maringá e Sarandi, 2018. 
Entre os que responderam que não houve uma integração, um representante da empresa destacou o fato de o projeto ser antigo e, outra, o fato de a localização ser no limite da divisa entre Maringá e Sarandi. Entre os que responderam que a obra favorece a integração, destaca-se, nas respostas, o fato de ir além das duas cidades, como se percebe nos depoimentos seguintes:

[D10] Favorece... acredito que ajuda bastante! Que nem eu falei, em termos da empresa, da pessoa jurídica nossa não tanto, mas eu como indivíduo, como cidadão, me sinto beneficiado, por exemplo, pra ir na minha casa, o contorno ajudou bastante. Nós temos bastante funcionários nossos que é de Sarandi, então, com certeza facilitou, tanto no trâmite, no deslocamento pessoal de cada um, como até da própria empresa pra ir em alguns lugares né... tem alternativas de trajeto. Com certeza, facilitou.

[D11] Favorece... nossa senhora... favorece, porque eu ando ali... nossa senhora, não tem nem o que falar... o fluxo que você pega de manhã aqui, que você pegava antigamente aqui... você sai, vamo supor, pra quem mora naquela região, lá pra cima, do Ouro Cola, lá pro lado da Coca-Cola e tem que trabalhar aqui pra Sarandi, pra que que você vai pegar uma Colombo, se você passa todo o fluxo pra sair aqui... na parte da manhã, ou seja, porque não tem nada, então você vem reto, lá na Noma lá que você vai... lá pra frente que você vai pegar um sinaleiro né.

[D12] Acho que favoreceu bastante né... Maringá, Sarandi, Astorga... Iguatemi, Mandaguaçú...

As entrevistas permitiram uma análise quanto aos empreendimentos envolvidos, cuja área se identifica como eixo de comércio e serviços, embora tenham sido repetidos nas entrevistas alguns problemas quanto à obra em si, como pontos de alagamento nas marginais em que o contorno se inicia, falta de sinalização, principalmente para os pedestres, na divisa entre as cidades envolvidas, e a barreira física entre as mesmas.

Quanto à economia urbana e regional, mais especificamente, os resultados são satisfatórios ao fundamentarem que o movimento dos negócios melhorou, bem como a percepção dos entrevistados quanto ao surgimento de novos empreendimentos com a finalização da obra e o favorecimento da integração entre Maringá e Sarandi, que também se estendeu a outras cidades da região. 


\section{Considerações finais}

O espaço urbano de Maringá estruturou-se seguindo um traçado definido, na época, como visionário e moderno, sendo projetada como uma cidade para até duzentos mil habitantes (ANDRADE, 1999). Entretanto, como passou a exercer grande força regional, seu peso demográfico logo se tornou iminente, o que desencadeou problemas estruturais, somados ao descompromisso do Estado e à especulação imobiliária, atingindo os municípios limítrofes e acentuando o processo de periferização interna e externa.

A fim de solucionar problemas quanto à adequação da infraestrutura urbana, um importante projeto viário foi elaborado como alternativa à Avenida Colombo, que era uma via limitadora, no plano inicial, e que se tornou indutora no processo de conurbação com Sarandi. O projeto Contorno Norte foi implementado vinte anos depois, justamente em uma área de periferização de Maringá e Sarandi, o que evidencia o controle do poder público sobre o urbano, que se mostra segregado socioespacialmente. Delimitada por meio de zonas, a área de estudo, cujo eixo é o de conurbação, definia-se como área de armazéns, devido a sua proximidade com a ferrovia. Devido à perda de função da área, que contempla principalmente empresas de transportes, outras empresas cujo uso do solo do eixo conurbado se divide em transporte, distribuição de cargas rodoviárias e revendas de automóveis, foram convidadas a participar das entrevistas.

A análise dos dados obtidos permitiu avaliar que com o Contorno Norte houve maior facilidade para o movimento dos negócios, viabilização da entrada e saída de caminhões, bem como agilidade nas entregas. Ambos os municípios se beneficiaram da obra em relação ao favorecimento de novos empreendimentos, embora existam relatos de trânsito intenso na divisa entre Maringá e Sarandi. O fluxo de veículos na Avenida Colombo apresentou melhora após a finalização do Contorno, apesar de haver algumas reclamações quanto à localização da obra, posta na entrada/saída de duas cidades e com mais entroncamentos do que o Contorno Sul, o que torna o acesso confuso às empresas localizadas na Avenida Colombo e ocasiona acidentes. Concordou-se que a 
obra não fomenta impactos negativos aos empreendimentos e que permitiu maior integração, não somente entre as cidades em questão, mas às demais, na região.

O estudo permitiu também aferir que a maioria dos benefícios definidos pelo DNIT, com a construção do Contorno, foram cumpridos, tais como: separação do tráfego de média e longa distância do local urbano e consequente redução da emissão de poluentes e ruídos no trecho da Avenida Colombo, embora este tenha sido apenas transposto para a via do Contorno, que não contorna a cidade como deveria; fluidez do tráfego, apesar de não ser possível afirmar a queda na quantidade de acidentes; e diminuição do tempo de viagem, principalmente para veículos de carga.

Observa-se, portanto, que o principal objetivo da obra do Contorno Norte foi atingido, pois, de acordo com as informações obtidas em campo, os entrevistados se mostraram otimistas quanto às transformações na dinâmica da Avenida Colombo, no eixo de conurbação entre as referidas cidades.

\section{Referências}

AMARAL FILHO, Jair do. A endogeneização no desenvolvimento econômico regional e local. Planejamento e políticas públicas, [S.I.]: IPEA, n. 23, jun. 2001, p. 261-286.

Disponível em: http://www.ipea.gov.br/ppp/index.php/PPP/article/viewFile/78/89. Acesso em: 15 de abr. de 2019.

ANDRADE, Carlos Roberto Monteiro et al. O urbanismo do engenheiro Jorge de Macedo Vieira. In: CATÁLOGO DA EXPOSIÇÃO: IV Bienal Internacional de Arquitetura de São Paulo. São Paulo: [s.n.], 1999.

BORGES, William Antonio; ROCHA, Márcio Mendes. A mobilidade centrada no trabalho e o processo de periferização no aglomerado urbano de Maringá. In: MENDES, Cesar Miranda; TOWS, Ricardo Luiz. Geografia urbana e temas transversais. Maringá: Eduem, 2009. p. 113-134.

BRANDÃO, Carlos Antonio. Teorias, estratégias e políticas regionais e urbanas recentes: anotações para uma agenda do desenvolvimento territorializado. Revista Paranaense de Desenvolvimento, Curitiba: IPARDES, n.107, p.55-74, jul./dez. 2004.

D1. [Entrevista cedidas a] Jaqueline Longen Rossatto, Sarandi/Maringá (PR), 15 jul. 2018. 
D2. [Entrevista cedidas a] Jaqueline Longen Rossatto, Sarandi/Maringá (PR), 15 jul. 2018.

D3. [Entrevista cedidas a] Jaqueline Longen Rossatto, Sarandi/Maringá (PR), 15 jul. 2018.

D4. [Entrevista cedidas a] Jaqueline Longen Rossatto, Sarandi/Maringá (PR), 15 jul. 2018.

D5. [Entrevista cedidas a] Jaqueline Longen Rossatto, Sarandi/Maringá (PR), 15 jul. 2018.

D6. [Entrevista cedidas a] Jaqueline Longen Rossatto, Sarandi/Maringá (PR), 15 jul. 2018.

D7. [Entrevista cedidas a] Jaqueline Longen Rossatto, Sarandi/Maringá (PR), 15 jul. 2018.

D8. [Entrevista cedidas a] Jaqueline Longen Rossatto, Sarandi/Maringá (PR), 15 jul. 2018.

D9. [Entrevista cedidas a] Jaqueline Longen Rossatto, Sarandi/Maringá (PR), 15 jul. 2018.

FRANCO, Gesli. BR-376 é a rodovia mais violenta do paraná. Gazeta do Povo, Curitiba, 22 out. 2014. Vida e Cidadania. Disponível em: https://www.gazetadopovo.com.br/vida-ecidadania/br-376-e-a-rodovia-mais-violenta-do-parana-ef9dkhkcqecevooq7si6o6v66/. Acesso em: 30 de out. 2018.

GIL, Antonio Carlos. Métodos e técnicas de pesquisa social. São Paulo: Atlas, 2008.

IBGE. Arranjos populacionais e concentrações urbanas no Brasil / IBGE, Coordenação de Geografia. Rio de Janeiro: IBGE, 2016. Disponível em: https://biblioteca.ibge.gov.br/ visualizacao/livros/liv99700.pdf. Data de acesso: 21 de maio de 2019.

IBGE. O recorte das Regiões Geográficas Imediatas e Intermediárias de 2017. Divisão Regional do Brasil em Regiões Geográficas imediatas e Regiões Geográficas Intermediárias. [S.I.]: IBGE, 2017. Disponível em: https://www.ibge.gov.br/apps/ regioes_geograficas/. Acesso em: 22 maio 2019.

IPARDES. Cadernos Municipais (Maringá e Sarandi). Disponível em: http://www.ipardes.gov.br/index.php?pg_conteudo=1\&cod_conteudo=30. Acesso em: 21 out. 2018.

IPEA. Caracterização e tendências da rede urbana do Brasil: redes urbanas regionais: Sul / IPEA / IBGE / UNICAMP / IE / NESUR, IPARDES. Brasília: IPEA, 2000.

\section{MINISTÉRIO DA INFRAESTRUTURA. Governo Federal inaugura nesta sexta-feira} Contorno Norte de Maringá na BR-376/PR. [Brasília: O Ministério, 2014]. Disponível em: http://infraestrutura.gov.br/component/content/article/17-ultimas-noticias/1876- 
governo-federal-inaugura-nesta-sexta-feira-contorno-norte-de-maring-na-br-376pr.html. Acesso em: 13 jun. 2019.

MOREIRA, Daniel Augusto. O método fenomenológico na pesquisa. São Paulo: Pioneira Thomson Learning, 2004.

POLÈSE, Mario. Economia urbana e regional: lógica espacial das transformações econômicas. Coimbra: Editora APDR, 1998.

RODRIGUES, Ana Lúcia. A pobreza mora ao lado: segregação socioespacial na região metropolitana de Maringá. São Paulo: Programa de Estudos pós-graduados em Ciências Sociais- Doutorado da Pontifícia Universidade Católica de São Paulo, 2004.

RODRIGUES, Ana Lúcia. et al. PAC Maringá "Contorno Norte": aprofundando o processo de segregação sócio espacial. Maringá: Programa de Pós-Graduação em Ciências Sociais - Observatório das Metrópoles - Núcleo Região Metropolitana de Maringá, 2011.

ROSSATTO, Jaqueline Longen. As implicações do contorno norte de Maringá (PR) em relação aos bairros de Maringá e à cidade de Sarandi (PR): um processo de segregação socioespacial. 2014. Trabalho de Conclusão de Curso (Bacharelado em Geografia) Universidade Estadual de Maringá, Centro de Ciências Humanas, Letras e Artes, Maringá, 2014.

ROSSATTO, Jaqueline Longen; SCHMIDT, Lisandro Pezzi Schmidt; COSTA, Pierre Alves. Pesquisa de campo no eixo conurbado Maringá e Sarandi. Sarandi e Maringá (PR), 15 jul. 2018.

SCOTT, Allen J. A economia metropolitana: organização industrial e crescimento urbano. BENKO, George.; LIPIETZ, Alain. (orgs.). As regiões ganhadoras - distritos e redes: os novos paradigmas da geografia econômica. Oeiras: Celata, 1994. p.63-73.

SCOTT, Allen J.; STORPER, Michael. A natureza das cidades: a abrangência e os limites da teoria urbana. Geografares, Vitória, p. 5-29, out./nov. 2018. Tradução Ana Maria Leite de Barros. Disponível em: periodicos.ufes.br/geografares/article/download/21999/14506. Acesso em: 17 abr. 2019.

TEIXEIRA, Maria Gracinda Carvalho; MORAES, Ivy Bertão de. O diálogo com as partes interessadas na teoria e na prática: análise da relação entre uma empresa pública do setor industrial e suas partes interessadas para criar uma política de responsabilidade social. Revista de Administração da UFSM, [Santa Maria], v. 6, p. 211-228, jul. 2013. Disponível em: https://periodicos.ufsm.br/reaufsm/article/view/8636. Acesso em: 13 de junho de 2019. 
VAINER, Carlos B. Pátria, empresa e mercadoria. Notas sobre a estratégia discursiva do Planejamento Estratégico Urbano. In: ARANTES, Otília; VAINER, Carlos, MARICATO, Ermínia. A cidade do pensamento único: desmanchando consensos, Petrópolis: Vozes, 2000. p. 75-103.

VERCEZI, Jaqueline Telma. O meio-técnico-científico-informacional e o espaço relativizado da Região Metropolitana de Maringá. 2012. Tese (Doutorado em Geografia) - Universidade Estadual de Maringá, Centro de Ciências Humanas, Letras e Artes, Maringá, 2012.

VILLAÇA, Flávio. Efeitos do espaço sobre o social na metrópole brasileira. In: ENCONTRO NACIONAL DA ANPUR, 7. 1997, Recife. Anais eletrônicos [...]. Recife, 1997. Disponível em: https://docplayer.com.br/11979463-Efeitos-do-espaco-sobre-o-social-na-metropolebrasileira.html. Acesso em: 20 abr. 2019.

WITTMANN, Milton. L.; DOTTO, Dalva M. R. Aglomerado de empresas. In: SIEDENBERG, Dieter Rugard (coord.). Dicionário do desenvolvimento regional. Santa Cruz do Sul: EDUNISC, 2006. p. 23. 